consists of a strip of rubber one-eighth of an inch thick, three inches long, and one and one-half inches wide. It is stapled to the screen, receives a straightwalled vial or an aspirating tube, and is self-closing.

For mid-limb feedings the cage can be opened, worked over the foliage, and when in position snapped shut over the limb. For terminal feedings, a wire or a cord may be attached from the free end of the cage to an upper limb; the cord supports the cage and so allows the foliage to be centred. For host range studies in the insectary, herbaceous plants from cherry orchards are grown in flower pots and the feeding cage clamped around them.

Sometimes large numbers of insects must be used for more than one feeding. In such cases the insects in the cage are anaesthetized, removed, and placed in a second feeding cage. Anaesthesia is accomplished by wrapping a sheet of oilcloth around the cage and inserting a piece of ether-soaked cotton through the insertion valve. If it is necessary to kill the insects, cyanide preparations may be employed in the same way. Cages must be well aerated after the use of cyanide.

The points of superiority of the bi-valve type of insect feeding cage over the others that have been used are: (1) It minimizes temperature increases. It prevents insect entanglement on the side of the cage as may be the case with muslin covering. (3) It simplifies introduction and removal of insects. (4) It protects insects from rain. (5) It is easily placed in position on the tree, is self-centring, and may be readily adapted for use on spur or twig. (6) It is low in cost, easy to construct, and very durable. (7) It is suitable for both field and insectary use.

The writer acknowledges with thanks the assistance of Mr. S. Cannings, Dominion Laboratory of Plant Pathology, Summerland, B.C., for making the photographs.

\title{
Blow Flies (Calliphoridae) in Alaska ${ }^{1}$
}

\author{
By REECE I. SAILER \\ Bureau of Entomology and Plant Quarantine \\ Agricultural Research Administration \\ United States Department of Agriculture \\ and Siegried E. Lienk \\ New York (Geneva) Agricultural Experiment Station
}

Several blow fly collections were made in the vicinity of Fairbanks between May 28 and June 14, 1948, and one large collection at Anchorage on August 9, 1948. All flies were caught in screen-wire fly traps baited with liver or dead salmon. The material was identified by D. G. Hall, Bureau of Entomology and Plant Quarantine, who also generously provided information concerning the possible importance of the various species of Alaskan blow flies.

Eight species of blow flies were represented in the eight collections examined (table 1). Of these, Protophormia terrae-novae (R.-D.) appears most likely to have public health significance in Alaska. This species was present in seven of the collections, and the number of specimens exceeded the total in the seven other species. P. terrae-novae was abundant from late May until at least the middle of August. Lucilia illustris (Meig.) and Calliphora terrae-novae Macq. were the next most numerous species; however, neither was taken before June 14 .

\footnotetext{
1These observations are based on material collected by the authors while they were members of the Alaskan Insect Project. This project was conducted by the Burau of Entomology and Plant Quarantine, U.S. Department of Agriculture, under a transfer of funds from the Department of Defense.
} 
TABLE 1.

Species of Blow Flies collected in Alaska in 1948

\begin{tabular}{|c|c|c|c|c|}
\hline \multirow{2}{*}{ Species } & \multicolumn{2}{|c|}{ Fairbanks } & \multicolumn{2}{|c|}{ Anchorage } \\
\hline & $\begin{array}{c}\text { No. of } \\
\text { Collections }\end{array}$ & $\begin{array}{l}\text { Total No. of } \\
\text { Specimens }\end{array}$ & $\begin{array}{l}\text { No. of } \\
\text { Collections }\end{array}$ & $\begin{array}{l}\text { Total No. of } \\
\text { Specimens }\end{array}$ \\
\hline Calliphora mortica Shannon. & - & - & 1 & 10 \\
\hline terrae-novae Macq... . & 2 & 26 & 1 & 129 \\
\hline vicina R.-D... & 1 & 3 & & \\
\hline vomitoria (L.) ........... & 1 & 5 & 1 & 8 \\
\hline Cynomyopsis cadaverina (R.-D.). & 3 & 13 & 1 & 23 \\
\hline Francilia alaskensis Shannon...... & 3 & 18 & & \\
\hline Lucilia illustris $(\mathrm{Mg}.) \ldots$ & 1 & 61 & 1 & 34 \\
\hline Protophormia terrae-novae (R.-D.). . & 7 & 407 & 1 & 15 \\
\hline
\end{tabular}

Lucilia illustris and Calliphora terrae-novae are not known to have public health significance in the United States and probably have little in Alaska. Protophormia terrae-novae, however, is known to produce wound myiasis in reindeer, sheep, and cattle, as well as to lay eggs on fresh meat and otherwise contaminate human food. In the United States some field-collected adults have also been found to be infected with the virus of poliomyelitis.

Published information concerning blow flies in Alaska is scanty and consists, for the most part, of species descriptions or distributional records buried in publications having no direct reference to Alaska. Hall (1948) includes most of this information in his book "The Blowflies of North America." However, it is necessary to examine the distribution data for each North American species in order to find those known from Alaska. The following list is based upon the records in Hall's book and a more recent paper by Weber (1950). In addition, the calliphorid collection of the U.S. National Museum has been examined and unpublished records included. With the exception of the material collected by the Canadian Arctic Expedition (Malloch 1919), virtually all published records are represented by material contained in the U.S. National Museum.

Acronesia alaskensis (Shannon)

\section{List of Species}

Nearctic.-ALASKA: Katmai, Naknek Lake, Kodiak, Seward. Also known in the U.S. from Yellowstone National Park and from Pingree Park, Colorado.

Acronesia aldricbia (Shannon)

Nearctic.-ALASKA: Seward, Naknek Lake. Distributed southward to

Washington, Wyoming, and eastward to Quebec.

Acronesia anana Hall

Nearctic-_ALASKA: Naknek Lake, Katmai.

Acronesia popoffana (Townsend)

Nearctic.-ALASKA: Naknek Lake, Popof Isl. Apaulina sapphira Hall

Nearctic.-ALASKA: Naknek Lake; Tok, 60 mi. east of, July 14, 1948, cliff swallow nest (second record for this bird screw-worm fly). 
Boreëllus atriceps (Zetterstedt)

Holarctic.-ALASKA: Pt. Barrow. Generally distributed across North

America above the Arctic Circle.

Calliphora coloradensis Hough

Nearctic.-ALASKA: Anchorage. South to San Martin, Mexico and east to

Indiana and Ontario.

Calliphora mortica Shannon

Nearctic.-ALASKA: Anchorage, Kodiak, Matanuska, Naknek Lake, Yaku-

lat. Also known from Slave Lake, Alberta.

Callipbora terrae-novae Macquart

Nearctic.-ALASKA: Anchorage, Cordova, Fairbanks, Juneau, Kukak Bay,

Matanuska, Naknek Lake, Nome, Seward, Skagway, Valdez, Virgins Bay,

Umiat, Upper Coleville River, Lat. $68^{\circ}+$, Long. $160^{\circ}$. The Nome record

is based on specimens collected by the Canadian Arctic Expedition which

were identified by Malloch (1919) as viridescens R.-D. Other American records for viridescens are now referred to C. livida Hall, a species not known to occur in Alaska.

In the rest of North America terrae-novae has been found as far south as Colorado and as far east as Newfoundland and New York.

Callipbora vicina $\mathrm{R}$.-D.

Holarctic and Neotropical.-ALASKA: Anchorage, Fairbanks, Umiat.

Widely distributed in the Western Hemisphere from Alaska and South

Greenland to Mexico City. The U.S. National Museum also contains

specimens collected from several localities in Chile and Uruguay.

Calliphora vomitoria (L.)

Holarctic.-ALASKA: Anchorage, Cordova, Howgan, Juneau, Katmai,

Kodiak, Matanuska, Naknek Lake, Nunivak Isl., Nushagak, Popof Isl., Port

Althorp, Seward, Sitka, St. Paul Isl., St. George Isl. Distributed in North

America from Alaska and West Greenland, south to California and Virginia.

Cynomya birta Hough

Nearctic.-ALASKA: St. George Isl., St. Paul Isl.

Cynomya mortuorum (L.)

Holarctic.-ALASKA: Amchitka Isl., Kukak Bay, Popof Isl., St. Paul Isl.,

St. George Isl.

Cynomyopsis cadaverina (R.-D.)

Nearctic.-ALASKA: Anchorage, Barter IsI., Cordova, Fairbanks, Konganevik (Camden Bay), Matanuska, Nome, Port Althorp, Pt. Barrow, Sitka, Skagway. Distributed over the rest of North America from Cambridge

Bay, Victoria Land; and West Greenland south to Brownsville, Texas.

Francilia alaskensis Shannon

Nearctic.-ALASKA: Anchorage, Camp 334 (Alaska Engineering Commission), Fairbanks, Mt. McKinley National Park, Naknek Lake, Old Crow. Also known from Churchill, Manitoba.

Lucilia illustris (Meigen)

Holarctic.-ALASKA: Anchorage, Fairbanks, Fox Point, Kodiak, Kukak Bay, Matanuska, Naknek Lake, Pt. Barrow, Rampart. Found in the rest of North America from Cambridge Bay, Victoria Land, south to northern Mexico.

Pbaenicia sericata (Meigen)

Reported by Weber from Pt. Barrow as Pbaenicia sp. His record was based on larvae collected from the carcass of a dog. Since $P$. sericata Meigen is virtually cosmopolitan in distribution and is at present the only species of 
the genus to be recorded from Canada, there seems little reason to doubt that Weber's record should be referred to this species.

Protophormia terrae-novae (R.-D.)

Holarctic.-ALASKA: Anchorage, Charis Peninsula, Chitina Glacier (30 mi. N. Mt. St. Elias), Collinson Point, Cordova, Demarcation Point, Fairbanks, Golovnin, Healy, Hurricane, Iditarod, Juneau, Koyukuk, Kowak River (Lat. $67^{\circ}-69^{\circ}$, Long. $151^{\circ}$ ), Kussiloff, Matanuska, Nenana, Nome,

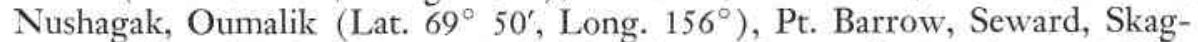
way, Teller, Umiat, Upper Coleville River (Lat. $68^{\circ} 47^{\prime}$, Long. $160^{\circ}$ ). Distributed over the rest of North America from Cambridge Bay, Victoria Land and West Greenland south to northern Georgia and northern Texas.

\section{Literature Cited}

Hall, D. G. 1948. The Blowflies of North America. 477 pp., 7 text figs., 5 color pls., 46 pls. The Thomas Say Foundation, Entomological Society of America.

Malloch, J. R. 1919. The Diptera collected by the Canadian Expedition, 1913-1918 (excluding the Tipulidae and Culicidae). Report of the Canadian Arctic Expedition 1913-1918. Vol. 3: Insects, Part C: Diptera, pp. 34-90, 3 pls.

Weber, N. A. 1950. A survey of insects and related arthropods of Arctic Alaska. Part I. Trans. Amer. Ent. Soc. 76: 147-206, 7 pls.

\section{Book Review}

A Field Guide to the Butterflies of North America, East of the Great Plains: By A. B. Klots. Pp. xvi and 349; with coloured illustrations of 247 species by Marjorie Statham and 232 photographs by Florence Longworth. Boston; Houghton Mifflin Company: $\$ 3.75$.

Since the profession of entomology has developed during recent times as a branch of agriculture and forestry, the work of its members is directed largely toward practical objectives, set by official bodies such as Departments of Agriculture. The research work involved therefore tends to become organized research in which teams of specialists coordinate their efforts with respect to some particular problem. That matters should take this course is probably inevitable; furthermore, the system of planned research by teams of specialists is well adapted to produce answers to questions of certain types, particularly in the practical field. But the specialist has been described as the man who gets to know more and more about less and less, and this intellectual myopia is not very favorable to scientific discovery of the most significant character.

A useful corrective, for the entomological team-worker is the maintenance of his amateur status. We tend to think of the amateur as a dilettante-jack of all trades and master of none-but the word amateur comes from amator and means the person who works at something because he likes it. To cultivate and maintain a lively interest in nature in general and insects in particular not only makes the existence of the economic entomologist more agreeable; it should also keep him mentally alert and more able to appreciate the interplay of the many factors involved in the problem of insect control.

For this purpose and for the encouragement of the non-professional entomologist, entomological handbooks of the type published by Mr. Klots are invaluable. Such handbooks, covering many aspects of natural history, are plentiful in European countries but in North America we are not yet very well supplied with them.

We cannot expect publishers to issue handbooks for all groups of insects. Plans for an all-embracing series have been made but they usually break down 